\title{
Hay Nutritional Quality and Grassland Bird Nesting: Impact of Delaying First Hay Cut on Dairy and Beef Production in Ontario
}

\author{
Paul G. R. Smith ${ }^{1,4}$, Matthew Wells ${ }^{2}$, John P. Cant ${ }^{2}$, Tom Wright ${ }^{1}$, Jack Kyle ${ }^{1,4}$, Peter Roberts ${ }^{1,4}$, \& Maria \\ Ramirez Giraldo ${ }^{3}$ \\ ${ }^{1}$ Ontario Ministry of Agriculture, Food and Rural Affairs, 1 Stone Road West, Guelph, ON, N1H 1R1, Canada \\ ${ }^{2}$ University of Guelph, Department of Animal Biosciences, Ontario Agricultural College, 50 Stone Road East, \\ Guelph, Ontario, N1G 2W1, Canada \\ ${ }^{3}$ Ontario Soil and Crop Improvement Association, 367 Woodlawn Rd. W., Unit 1, Guelph, Ontario, N1H 7K9, \\ Canada \\ ${ }^{4}$ Retired \\ Correspondence: Paul G. R. Smith, 33 Division Street, Guelph, ON, N1H 1R1, Canada. E-mail: \\ paul@paulsmith.work
}

Received: January 1, 2022 Accepted: February 22, 2022 Online Published: March 8, 2022

doi:10.5539/sar.v11n2p14 URL: https://doi.org/10.5539/sar.v11n2p14

\begin{abstract}
Perennial forage production exists in Ontario to support the livestock industry, but also provides nesting habitat for grassland birds such as the threatened Bobolink (Dolichonyx oryzivorus) and Eastern Meadowlark (Sturnella magna). Delaying hay harvest until July 15 or later allows most nestling birds to leave the nest, but the nutritional value of hay decreases substantially. This project estimated the nutritional and economic impact of delaying the first hay cut until after July 15 on beef and dairy production in Ontario, Canada. Forage crops were sampled across Ontario, analysis of nutritional value performed, and effects on production and economics modelled. 634 samples were collected over 13 weeks at 16 sites from May 21 to August 14 during 2014 and 2015. As expected, nutritional quality declined over the season. Crude protein decreased by $5.2 \%$, total digestible nutrients by $7.7 \%$, neutral detergent fibre digestibility (NDFd48) by $20.1 \%$, while lignin increased by $3.5 \%$, neutral detergent fibre by $13.1 \%$, and acid detergent fibre by $9.9 \%$. Estimated yearly milk production decreased $10.9 \mathrm{~kg}$ or C\$7.87/dairy cow for each day of delay in harvest (2017 values). Estimated growth of backgrounding beef steers decreased $1.56 \mathrm{~kg}$ or $\mathrm{C} \$ 5.49 /$ head for each day of delay in harvest. This translated into lost revenue per acre for backgrounding steers of $\mathrm{C} \$ 31$ per acre and $\mathrm{C} \$ 45$ per acre for over wintering beef cows for a delay from mid-June to mid-July. Some agri-environmental incentives in Canada, US and Europe offset the reduced revenue due to lower quality forages. This analysis informs farmers about the cost of practices to benefit grassland birds and provides empirical data on how to structure stewardship incentives for these practices.
\end{abstract}

Keywords: forage, hay, pasture, ruminant nutrition, grassland birds, bobolink, Dolichonyx oryzivorus, eastern meadowlark, Sturnella magna

\section{Introduction}

\subsection{The Dilemma of Forage Production Economics and Grassland Bird Conservation}

Perennial forage production, both hay and pasture, is an important agricultural industry estimated in value at C\$650 million in Ontario of a total C\$5.1 billion in Canada in 2012 and supports livestock agriculture, including beef, dairy, sheep, horse, and other sectors (Brookfield, 2016; Yungblut, 2012; Fisher, 2008). In 2016, perennial forages, hay and pasture, were grown on over 20,000 farms and covering 1.2 million hectares of farmland in Ontario and 25.1 million hectares in Canada in 2016 (Statistics Canada, 2017). During the $20^{\text {th }}$ and early $21^{\text {st }}$ centuries, for various reasons, Ontario agriculture shifted to greater focus on annual crops. Hay and pasture area has declined dramatically (Smith, 2018, 2015), as it has across North America (Stanton et al., 2018), and many developed countries in recent decades (OECD, 2019).

Grassland birds, such as the Bobolink (Dolichonyx oryzivorus) and Eastern Meadowlark (Sturnella magna), commonly nest in tame pasture and hay production fields in many parts of Ontario (Ethier, Koper \& Nudds, 2017; McCracken et al., 2013), while occupying native prairie and rangeland in other parts of North America 
(North American Bird Conservation Initiative Canada, 2019; Renfrew et al., 2019; Wilsey, et al., 2019). In pre-European colonization conditions in Ontario, grassland birds were restricted to natural grasslands, wet meadows and habitats created by Indigenous peoples' landscape management (McCracken et al., 2013). Populations of grassland birds increased in Ontario with European-style agriculture during the $18^{\text {th }}$ and $19^{\text {th }}$ centuries, especially large areas of pasture and hay to support horses and ruminants (Smith, 2018, 2015; McCracken et al., 2013). Today the nesting of many grassland-nesting species depends on the shrinking area of pasture and hay on working agricultural lands with its concomitant grazing and harvesting, east of the extensive prairie ecosystems (Renfrew et al., 2019).

To improve understanding of trade-offs between forage nutritional quality, economics and grassland bird nesting success, this study quantified the change in the nutritional quality of Ontario forages over the growing season from mid-May to mid-August and modeled the nutritional, production and economic impacts of delaying hay harvest.

\subsection{Bird Species Conservation Status}

Bobolink and Eastern Meadowlark were designated threatened species in 2010 and 2012 respectively under Ontario's Endangered Species Act and in 2010 and 2011 under Canada's federal Species at Risk Act due to their declining populations (Smith, 2018; McCracken et al., 2013). Better understanding of the economic impact of practices to benefit grassland birds was identified as a research priority in the recovery strategy for these species (Ontario Ministry of Environment, Conservation and Parks, 2020; McCracken et al., 2013). This paper helps address that research priority. It also builds on previous analysis of the economic impact (Mussell et al., 2013) and some nutritional analyses included in grassland bird ecology studies (Diemera \& Nocera, 2016; Brown \& Nocera, 2017).

The specific causes of declining grassland bird populations are complex but failure of young birds to survive and reproduce is clearly a major concern (North American Bird Conservation Initiative Canada, 2019; Renfrew et al. 2019; Wilsey et al., 2019; Stanton, Morrissey, \& Clark, 2018; Ethier et al., 2017; Ethier \& Nudds, 2015; Hill et al., 2014; McCracken et al., 2013). Young birds depend on their parents for food for a long period and are especially vulnerable until they fledge. Hay harvest or grazing before the young birds fledge can result in bird mortality. Biologists estimate most young Bobolinks leave the nest in Ontario by July 15 in most years (Put et al., 2020; Campomizzi et al., 2019; Pintaric, 2018; Brown and Nocera, 2017; Diemer and Nocera, 2016). July 15 is quite late from a forage nutritional quality perspective (Diemera and Nocera, 2016; Mussell et al., 2013; Berdahl, Karn, \& Hendrickson, 2004; Ball et al., 2001). In addition, if harvest only began after July 15, the overall first cut harvest period would extend well into August.

\subsection{Forage Production}

The science of forage production has long established the decline of nutritional value of forages through the growing season and sought to identify optimal harvest times (Moore, Lenssen, \& Fales, 2020; Karn et al., 2004; Ball et al., 2001; Upfold and Wright, 1994). As perennial forages (hay) mature over the season there is a natural, inevitable drop in quality. Mature forages contain a higher ratio of stems to leaves, lower levels of available protein and non-structural carbohydrates, and higher amounts of fibre, providing limited energy and lower digestibility in both grasses and legumes (Foster et al., 2021; Jensen et al., 2017; Palmonari et al., 2014; Yari et al., 2012; Berdahl, Karn, \& Hendrickson, 2004).

The species composition of perennial forage crops is variable but generally includes legumes and grasses in differing mixtures tailored to site conditions and livestock species (Ontario Ministry of Agriculture, Food and Rural Affairs, 2009; Upfold \& Wright, 1994). Forage grown for dairy production tends to be primarily alfalfa-dominated (Medicago sativa L.; Roche et al., 2017), while forage for beef, sheep and other livestock species may have more grass species and include other legumes. Bobolink and Eastern Meadowlark are more numerous in grass-dominated hay fields but do nest in all types of hay (McCracken et al., 2013). As well, alfalfa-dominated hay grown for dairy production is usually harvested much earlier and more often than grass-dominated hay, to meet the higher nutritional needs. This combination of factors has led to some grassland bird conservation efforts to focus on mixed forage crops grown for beef, sheep, and other livestock, rather than alfalfa-dominated forage grown for dairy production (Diemera \& Nocera, 2016; McCracken et al., 2013).

\subsection{Conservation Measures}

The trade-offs between conservation of grassland bird nesting and forage nutritional value for livestock and farm economics are becoming familiar. In Europe, many farmland, grassland, and meadow bird species also depend on agricultural grasslands and delaying forage harvest is often recommended (OECD, 2019; Broyer et al., 2016). 
Stewardship funding and extension programs seek to address these trade-offs. Educational materials and tools allow farmers to assess those trade-offs and make informed decisions (e.g., Kyle \& Reid, 2015).

Some agri-environmental incentive programs in Europe, United States, and Canada offer incentives to offset the reduced revenue due to lower quality forages (OECD, 2019; Smith, 2018; Perlut et al., 2011). Several US Farm Bill programs offer incentives, such as the US Conservation Reserve Program that funds setting aside land until after the nesting period (Shew et al., 2021). In Vermont, the Wildlife Habitat Incentive Program provided reimbursement of up to US\$62/ha (C\$33 / acre) for delayed hay cutting in 2008-2009 (Perlut et al., 2011). An ecological services valuation approach was also tried in the US, raising funds from the public for on-farm Bobolink conservation (Swallow et al., 2018).

Europe has a long history with conserving farmland birds and plant and animal species on farmland and semi-natural habitats and has well-funded agri-environmental schemes focused on biodiversity (OECD, 2019). So European agri-environmental schemes offer significant incentives for biodiversity conservation including farmland, grassland, and meadow birds (e.g., as much as $£ 260$ /ha, or C $\$ 183$ / acre for the endangered Corn Crake; Perkins et al., 2011).

In Ontario, the Species at Risk Partnerships on Agricultural Lands program and the Grassland Stewardship Program provided up to C \$40/ac/year for delayed haying (Johnson, 2020; Ontario Soil and Crop Improvement Association, 2022, 2018). A PEI program offered farmers C $\$ 25$ / acre for delayed haying to benefit grassland birds (Johnson, 2020).

\subsection{Study Purpose}

This study quantified the change in nutritional quality of Ontario forages over the growing season from mid-May to mid-August and estimated the production and economic effects in beef and dairy production systems. This is to improve understanding of the trade-offs between forage nutritional quality, economics, and grassland bird nesting success. Estimates of the reduced quality of forage allow the calculation of reduced animal weight gain or milk production, and from that the estimation of economic impact based on costs and prices. These in turn allow for calculation of reduced economic value of hay on a per acre basis based on average hay yields. These estimates inform evidence-based educational materials and stewardship programs that assist farmers in decision-making regarding practices to benefit grassland birds.

\section{Methods}

\subsection{Field Sampling and Locations}

Perennial forage (hay) samples were collected weekly at 16 cooperating farm sites across Ontario from May 21 August 14 of 2014 and 2015 (Table 1 and Figure 1; two sites were sampled only in 2014), (for detail see Wells et al. 2018). This extends beyond the usual first-cut hay harvest dates to mid-August to reflect an extended season under hypothetical delayed start of hay harvest until July 15, with hay harvest continuing until complete.

On cooperating farms, a section of each field was cordoned off and left unharvested and undisturbed for sampling throughout the duration of the project. Samples were taken from a $45.7 \times 45.7 \mathrm{~cm}(18 \times 18 \mathrm{inch})$ plot by cutting the forage $7.6 \mathrm{~cm}$ (three inches) above the ground. One or two samples were taken each week for 12-13 weeks. 634 forage samples were collected for analysis, 292 in 2014 and 342 in 2015. Collected samples were weighed, bagged and frozen until delivered to the lab for analysis.

Figure 1 shows the geographic locations of the 16 sampling sites as well as the area of hay by township in Ontario (2011 census). The sampling sites were selected to reflect the differences in growing conditions across the province and predominant areas of forage production. The sites reflect a wide range of values of Crop Heat Units for production from 2400-3100 (Table 1), covering most common growing conditions for forages. The sites include different species mixes (Table 1): legume (alfalfa-dominated), grass (grass-dominated) or mixed (a relatively equal mixture of legumes and grasses). Where possible, sites with all three types of forage categories were sampled in each geographic region. The sampling sites were grouped into four regions and location data are noted in Table 1 and used in nutritional modeling. The two northern Ontario sites are excluded from regional comparisons due to small sample size for the northern region. 


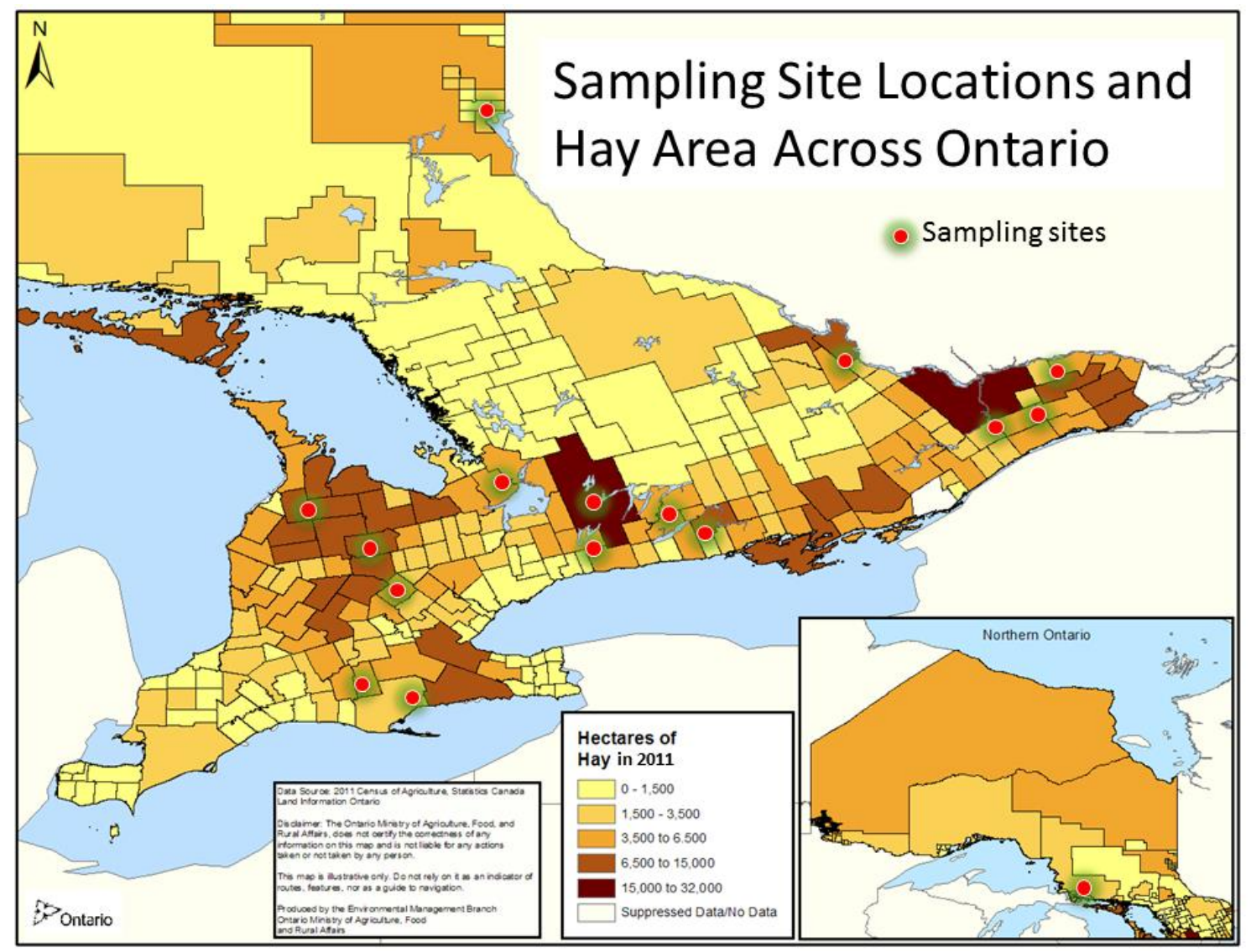

Figure 1. Sampling site locations and hay area across Ontario

Table 1. Location and characteristics of sampling sites for delayed harvest forage nutritional study

\begin{tabular}{lllll}
\hline Region & County, Region, & Sampling & Crop Heat & Type of Forage \\
& District & Site Location & Units & \\
\hline Southwestern Ontario & Norfolk County & St. Williams & 3100 & Grass-dominated \\
& Oxford County & Embro & 2900 & Legume-dominated \\
& Bruce County & Chesley & 2700 & Grass-dominated \\
& Wellington County & Elora & 2700 & Legume-dominated \\
& Grey County & Dundalk & 2500 & Grass-dominated \\
Southeastern Ontario & Prescott and Russell & Alfred & 2900 & Mixed \\
& Leeds and Grenville & Kemptville & 2900 & Grass-dominated \\
& Stormont, Dundas and Glengarry & Winchester & 2900 & Legume-dominated \\
& Renfrew & Renfrew & 2700 & Grass-dominated \\
Southcentral Ontario & Kawartha Lakes (formerly Victoria) & Cambray & 2700 & Grass-dominated \\
& Durham Region & Enniskillen & 2900 & Legume-dominated \\
& Peterborough County & Keene & 2700 & Grass-dominated \\
& Northumberland County & Warkworth & 2900 & Mixed \\
& Simcoe County & Oro & 2700 & Grass-dominated \\
Northern Ontario & Algoma District & Echo Bay & 2500 & Grass-dominated \\
& Timiskaming District & New Liskeard & 2400 & Grass-dominated \\
\hline
\end{tabular}

\subsection{Laboratory Analysis}

Forage samples were analyzed at a commercial feed laboratory (A\&L Canada Laboratories Ltd., London, Ontario). This is the first systematic survey over time (season and year) of forage quality in Ontario that analyzed samples for neutral detergent fibre digestibility (NDFd48), a forage analysis method that assesses NDF digestibility using an in vitro system that approximates the true digestibility in the rumen. Samples were 
analyzed for NDFd using the Daisy II incubator (Ankom Technology, Macedon, New York) using the Van Soest buffers for macro and micro solutions. In vitro true digestibility was determined using Ankom Technology Method 3. After the required in vitro incubation time, NDF was determined using Ankom Method 6, Neutral Detergent Fibre in Feeds - FBT for A2 fibre analyzer.

Laboratory analyses were performed on each sample (634 samples) to determine the concentration of dry matter $(\mathrm{DM})$, neutral detergent fibre (NDF), acid detergent fibre (ADF), crude protein (CP), soluble protein, undegradable intake protein (UIP), lignin, and other variables such as micronutrients. Neutral Detergent Fibre Digestibility (NDFd48) was also measured to assess digestibility in rumen fluid (for 48 hours, see more below). Key variables are defined, and their significance described below (Weiss \& Hall, 2020; Ontario Ministry of Agriculture, Food and Rural Affairs, 2016; Ball et al., 2001).

Dry Matter - is the moisture-free material left after drying the sample in a laboratory oven. It is standard practice to evaluate the feed and balance rations using a dry matter basis.

Crude Protein (CP) - is calculated based on the nitrogen content of the feed. Protein is approximately $16 \%$ nitrogen and total nitrogen is measured to calculate a value for crude protein. $\mathrm{CP}$ is expressed as a percent of dry matter.

Soluble Crude Protein - is most readily available to animals and can be absorbed across the rumen wall. Soluble protein is expressed as a percentage of total crude protein.

Undegradable Intake Protein (UIP) - or by-pass protein, is the fraction of protein that is resistant to degradation by rumen microbes. UIP is expressed as a percentage of total crude protein.

Acid Detergent Fibre (ADF) - refers to the cell wall portion of forage, made up of lignin and cellulose. The value reflects the ability of animals to digest the forage. ADF represents the portion of hay that doesn't dissolve in an acid detergent solution. It has a strong (negative) relationship with total forage digestibility. ADF is used to define guidelines for hay quality, as ADF increases, forage quality declines. ADF is expressed as a percent of dry matter.

Neutral Detergent Fibre (NDF) - refers to the cell wall fraction that includes ADF and hemicellulose. The NDF value is related to the amount of forage the animal can consume and as NDF increases, the dry matter intake generally decreases. NDF is expressed as a percent of dry matter.

Neutral Detergent Fibre Digestibility (NDFd) - is feed digestibility in rumen fluid based on 48 hours (NDFd48) in an in-vitro digestibility analysis. It measures how much of the feed has been digested by the microbes in rumen fluid after 48 hours. NDFd48 is expressed as a percent of NDF.

Total Digestible Nutrients (TDN) - an equation is used to calculate energy or total digestible nutrients (TDN). This is the first limiting parameter for milk production. This measure includes NDF, lignin, fat, starch, mineral and bound protein and is used to estimate energy values. TDN is expressed as a percent of dry matter.

Lignin - is the indigestible portion of the plant cell and increases with the maturity of the forage. Lignin negatively affects the digestion of the cell wall by acting as a physical barrier to the microbial enzymes. Lignin is expressed as a percent of dry matter.

Statistical analysis of the laboratory nutritional analysis data was undertaken using Microsoft Excel and associated statistical add-ins and PSPP statistical analysis software version 1.4.1. Analytical tools include analysis of variance, regression, and correlation.

\subsection{Nutritional Modeling and Economic Analysis Methods}

Modeling methods were used to estimate the effects on milk production and weight gain in livestock fed rations including forages harvested on different dates. The standard National Research Council models for livestock production were used for estimates for dairy (National Research Council, 2001) and beef production (National Academies of Sciences, Engineering, and Medicine, 2016). These models are sets of equations developed by industry experts to predict production outcomes of animals fed varying diets, based on decades of research and are viewed as industry and academic standards.

For the nutritional modeling study, provincial level results included all sites and samples. Regional estimates were made based on the sites grouped into the four regions (Table 1) and the nutritional data was averaged to provide a single value for each sampling week for each region. Region-specific results for northern region sites are not presented here due to the small sample size, but the northern sites' data are included in provincial level estimates. 
The modelling required inputs regarding composition of feed rations, weight gain, milk production, hay yield, prices, costs, and other factors for each scenario. These are outlined with the results for each scenario.

\section{Results}

\subsection{Forage Sampling}

Table 2 shows the average value, percent change and correlation with date of first cut May to August for eight key nutritional parameters. Most variables associated with positive nutritional value decline significantly through the season including Crude Protein (CP), Neutral Detergent Fibre Digestibility (NDFd48) and Total Digestible Nutrients (TDN). Soluble Crude Protein and Undegradable Intake Protein (UIP) changed relatively little. Variables indicative of low digestibility increased over the season, Lignin, Acid Detergent Fibre (ADF) and Neutral Detergent Fibre (NDF). Again, these results are typical and reflect well known trends in seasonal forage quality (e.g., Berdahl et al., 2004; Ball et al., 2001; Upfold \& Wright, 1994).

Table 2. Change in nutritional parameters of forage first harvested from May to August and correlation with date, averaged for all sites

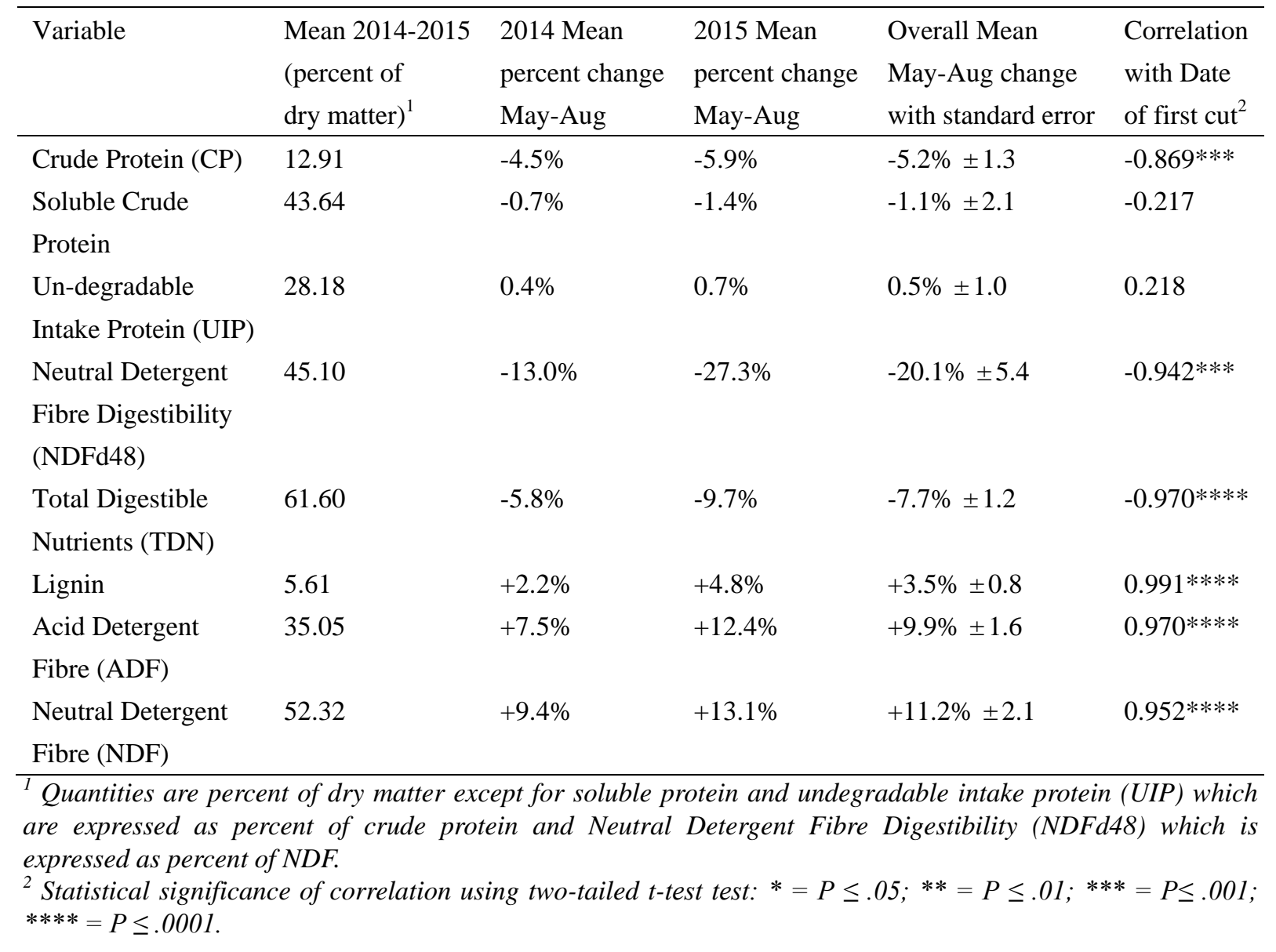

The values of all variables were significantly different among sites (ANOVA, F-test, $\mathrm{p}<0.001$ ). Some variables varied significantly between the regions identified in Table 1 (CP, ADF, NDF, NDFd48, TDN, Lignin; ANOVA, F-test, $\mathrm{p}<0.05$ or more significant). Many of the nutritional variables showed a statistically significant influence from crop heat units (CP, ADF, NDFd48, TDN, soluble protein, UIP, Lignin) while controlling for seasonal change as a covariate (ANOVA with covariate, F-test, $\mathrm{p}<0.001$ ). Forage species mixture type also significantly influenced some nutritional variables (CP, NDF, NDFd48, Soluble Protein, UIP, Lignin, ANOVA, F-test, p $<0.05$ or more significant). Such results are expected.

\subsection{Nutrition Modeling}

The nutrition modeling uses the lab analysis of forage samples as inputs into standard nutrition models to estimate the effect of decreasing nutritional quality over the season on milk production and weight gain. Modeling included analyses for: dairy cows, beef steers and beef cows. Results for each of these are presented 
below.

\subsubsection{Nutrition Modeling Results: Dairy}

Most lactating dairy cows in Ontario are fed a total mixed ration (TMR) containing some combination of corn silage, concentrated energy, protein and vitamin/mineral supplements, and forages, usually in the form of an alfalfa silage (haylage). The 2001 NRC dairy equations were used to generate estimates of how feeding forages harvested at each timepoint during the summer would affect milk production.

The following assumptions were made when using the dairy software:

- Mature cows with a body weight of $681 \mathrm{~kg}$

- The average milk yield is $36 \mathrm{~kg} / \mathrm{day}$

- The cows are 105 Days in Milk

The following diet (on a dry matter basis), which is representative of a typical Ontario ration, was used for all calculations, with the quality of all ingredients, other than hay, being constant:

- $3.6 \%$ straw

- $\mathbf{2 5 . 5 \%}$ of the sampled hay

- $38 \%$ corn silage, containing $40 \%$ grain

- $19.4 \%$ high moisture corn

- $13.5 \%$ custom concentrate

Estimated milk production (as measured by net energy or NE allowable milk and metabolizable protein or MP allowable milk), and protein intake (CP crude protein, MPI metabolizable protein intake) all decreased over the season, declining with the decreasing quality of forage already noted (Table 3 ).

The decline in estimated milk production (Table 3) using forage harvested later shows the impact of the maturity of forage samples on milk production. Milk production is determined by dietary energy and protein availability. Energy is utilized by microbes in the cow's rumen which ferment the carbohydrates into volatile fatty acids (VFAs) utilized by the cow as energy and to synthesize lactose and fatty acids.

Dietary protein is found in two forms: rumen degradable protein (RDP) and undegradable protein (UIP). The rumen microbes utilize the RDP to synthesize their microbial proteins that flow out of the rumen and are digested in the cow's small intestine. UIP is unavailable to the rumen microbes, but can be available to the cow, if the protein can be digested by the cow's own enzymes, which is dependent on the protein being unbound from fibre. Neutral detergent (hemicellulose) bound crude protein may be freed by the rumen microbes, but is unavailable once past the rumen, acid detergent (cellulose + lignin) bound protein is completely unavailable and will pass through undigested.

Table 3. Change in dairy cows' estimated milk production and protein intake on a diet including forage first cut May-August 2015

\begin{tabular}{lllll}
\hline & $\begin{array}{l}\text { Mean } \\
\text { value }\end{array}$ & $\begin{array}{l}\text { Percent change } \\
\text { over season }\end{array}$ & $\begin{array}{l}\text { Correlation with } \\
\text { date of first cut }\end{array}$ & $\mathrm{R}^{2}$ \\
\hline Net energy allowable milk (kg/day) & 35.5 & -4.21 & $-0.966^{* * * *}$ & $93.3 \%$ \\
Metabolizable protein allowable milk (kg/day) & 36.0 & -8.32 & $-0.827 * * *$ & $68.3 \%$ \\
Crude protein intake kg/d & 3.7 & -9.34 & $-0.828 * * *$ & $68.5 \%$ \\
Metabolizable protein intake g/d & 2551.0 & -4.68 & $-0.824 * * *$ & $67.9 \%$ \\
\hline tatistical significance of two-tailed t-test test reported: $*=\mathrm{P} \leq .05 ; * *=\mathrm{P} \leq .01 ; * * *=\mathrm{P} \leq .001 ;$ \\
$* \mathrm{P} \leq .0001$.
\end{tabular}

The amount and availability of protein is important as it determines how much protein is available to support lactation. Net energy and metabolizable protein are both critical to supporting milk production and a decrease in either will cause a loss in milk production.

Both crude protein and metabolizable protein intake (MPI) decline in hay harvested May-August (Table 3). The trend in MPI shows the effect of the maturing sampled forages on protein intakes and retention. MPI indicates the level of crude protein in the diet and how available the protein is to the animal.

These trends are expected as mature forages contain a greater ratio of stems to leaves. The leaves drive forage value with high levels of available protein and non-structural carbohydrates, providing energy. Stems are composed of primarily fibre as NDF and ADF, providing limited energy and much of the protein is fibre-bound. 
As forage is left to mature, more volume of forage accumulates, but mostly from stem growth, increasing NDF and ADF and diluting available energy and protein.

\subsubsection{Nutrition Modeling Results: Beef Steers}

For the analysis for beef steers, feed information was input into the feed library of the Beef Cattle Nutrient Requirements Model 2016 (National Academies of Sciences, Engineering, and Medicine, 2016). The following assumptions were made for all calculations:

- Diet fed to Angus steers on a backgrounding program

- Initial body weight of $226 \mathrm{~kg}$ (500lb) and finishing at $408 \mathrm{~kg}$ (900lb)

- Steers were fed a $100 \%$-forage diet, consisting of the sampled forage

- Steers would be fed ad libitum, therefore the input dry matter intake (DMI) was matched to the predicted DMI

Beef steer weight gain decreased over the season with decreasing forage quality as illustrated in Table 4 . The measures of weight gain are metabolizable energy (ME) allowable gain and metabolizable protein (MP) allowable gain. ME and MP allowable gain follow the same principles as NE and MP allowable milk for dairy cows, but for backgrounding beef steers the energy and protein are being utilized to support structural growth of muscle tissue.

Table 4. Trends in beef steer estimated weight gain on a diet of forages harvested May-August 2015

\begin{tabular}{lllll}
\hline & $\begin{array}{l}\text { Mean } \\
\text { value }\end{array}$ & $\begin{array}{l}\text { Percent Change } \\
\text { over season }\end{array}$ & $\begin{array}{l}\text { Correlation with } \\
\text { date of first cut }\end{array}$ & $\mathrm{R}^{2}$ \\
\hline Metabolizable Energy allowable gain (kg/day) & 0.762 & $-58.8 \%$ & $-0.984 * * * *$ & $96.8 \%$ \\
Metabolizable protein allowable gain (kg/day) & 0.726 & $-35.9 \%$ & $-0.945^{* * * * *}$ & $89.3 \%$ \\
Expected Dry Matter Intake (kg/day) & 7.4 & $0.63 \%$ & $0.648^{*}$ & $41.9 \%$ \\
\hline Statistical significance of two-tailed t-test test: $*=\mathrm{P} \leq .05 ; * *=\mathrm{P} \leq .01 ; * * *=\mathrm{P} \leq .001 ; * * * *=\mathrm{P} \leq .0001$.
\end{tabular}

The primary production parameter for beef cattle is daily body weight gain and it tended to decrease, similarly to the predicted milk production for dairy cattle, as the rations included forage from lower quality later harvests. These results are due to the increase in the proportion of stems in the mature forage, causing an increase in fibre and decrease in the concentration of energy and protein. While dry matter intake increased some, the steers cannot eat enough to compensate for the lower nutrient concentration, resulting in lost production.

\subsubsection{Nutrition Modeling Results: Wintering Beef Cows}

For the analysis for feeding wintering beef cows, forage feed information was input into the feed library of the Beef Cattle Nutrient Requirements Model 2016 (National Academies of Sciences, Engineering, and Medicine, 2016). The following assumptions were made for all calculations:

- Diet is being fed to 3-year-old Angus cows being over-wintered

- Cows have a mature weight of $532 \mathrm{~kg}(1170 \mathrm{lb})$

- Cows are 200 days pregnant and give birth to a $40 \mathrm{~kg}$ calf in April, therefore non-lactating

- Average outdoor temperature is $-5 \mathrm{C}$, with average lows of $-10 \mathrm{C}$ and wind speeds of $15 \mathrm{~km} / \mathrm{h}$. The cows are assumed to be sheltered.

- Cows are fed harvested forage from October to April (180 days)

- Cows are fed enough of sampled forage to exceed energy requirements by $0.5 \mathrm{Mcal} / \mathrm{day}$

This model scenario differs from the others in that DMI is allowed to increase to exceed the daily energy requirements noted above. The DMI is also required to slightly exceed energy requirements, which represents the primary cost of keeping a mature beef cow over the winter. With a drop in feed quality, cows need to eat more to meet their nutrient requirements. This is reflected in the increase in DMI using forage harvested later in the period May-August (Table 5). Linked to the increased DMI for late season forage, both metabolizable energy (ME) and metabolizable protein (MP) also increase with the later season forage. Days to gain one body condition score are included to demonstrate that the cows are being fed just enough to slightly exceed requirements, as a cow fed to her maximum intake could gain one body condition score (BCS) every 30 days (Table 5). Increases in forage maturity resulted in a need for higher feed intakes to meet the cow's nutritional requirements. 
Table 5. Wintering Beef Cows: Trends in dry matter intake, weight gain, energy, and protein on a diet of forage harvested May-August 2015

\begin{tabular}{lllll}
\hline & Average & $\begin{array}{l}\text { Percent change } \\
\text { over season }\end{array}$ & $\begin{array}{l}\text { Correlation with } \\
\text { date of first cut }^{1}\end{array}$ & $\mathrm{R}^{2}$ \\
\hline Dry Matter Intake (kg/d) & 7.52 & $+25.0 \%$ & $0.978^{* * * * *}$ & $95.7 \%$ \\
Metabolizable Energy provided (Mcal/d) & 16.82 & $+7.1 \%$ & $0.975^{* * * * *}$ & $95.0 \%$ \\
Metabolizable Protein provided (g/d) & 508.9 & $+9.3 \%$ & $0.955^{* * * *}$ & $91.2 \%$ \\
Days to gain one Body Condition Score & 298.73 & $-1.6 \%$ & -0.492 & $24.2 \%$ \\
\hline
\end{tabular}

${ }^{1}$ Statistical significance of two-tailed t-test test: $*=\mathrm{P} \leq .05 ; * *=\mathrm{P} \leq .01 ; * * *=\mathrm{P} \leq .001$;

$* * * *=\mathrm{P} \leq .0001$.

\subsection{Results: Production Loss and Economics}

Based on the documented decreases in nutritional value of forages, milk output, and weight gain, all showed linear declines over the season. To determine the opportunity cost of lost production due to delaying harvest by an additional day, linear regression models predicting production loss per day of delayed harvest were calculated from the relationships illustrated in Table 3 and Table 5. The models were then adjusted to an annual scale to be more relevant and simpler to interpret. Predictions of the lost revenue per animal per unit time were made by multiplying the production models with market prices.

\subsubsection{Dairy and Beef}

Predicted milk yields from diets containing the sampled forages declined over the season (Table 3 and Table 5). The economic value of lost milk production due to time of harvest was estimated based on March 2017 sale prices of milk components of $\mathrm{C} \$ 10.71 / \mathrm{kg}$ fat, $\mathrm{C} \$ 7.45 / \mathrm{kg}$ protein and $\mathrm{C} \$ 1.52 / \mathrm{kg}$ other solids, assuming $3.8 \%$ fat, $3.1 \%$ protein and 5.5\% other solids in the predicted milk yields (Dairy Farmers of Ontario website, March 2017). For each day of delayed harvest, annual revenue from milk sales was predicted to decline $\mathrm{C} \$ 7.87 / \mathrm{cow}$ provincially, or C $\$ 4.65 / \mathrm{cow}, \mathrm{C} \$ 5.16 / \mathrm{cow}$, and $\mathrm{C} \$ 7.41 / \mathrm{cow}$ for Southcentral, Southeastern, and Southwestern Ontario, respectively (Table 6).

For an average 80-cow dairy farm in Ontario, the revenue loss is expected to be $\mathrm{C} \$ 630$ for each additional day of delay, which is equivalent to $C \$ 19,000$ for 30 days of delay and $C \$ 38,000$ for 60 days of delay. 30 days would represent a delay from mid-June, generally an optimal time for harvest nutritionally, to mid-July, optimal for the fledging of nestling birds. First cut in forage for dairy is often in mid to late May, closer to a 60-day difference between mid-May and mid-July.

The economic value of lost bodyweight gain in beef cattle was estimated based on an average April 2017 auction price of $\mathrm{C} \$ 3.52 / \mathrm{kg}$ live weight and a backgrounding duration of $400 \mathrm{~d}$. For each day of extending the harvest, reduced weight gain was equivalent to $\mathrm{C} \$ 5.49 /$ head provincially, or $\mathrm{C} \$ 6.96 /$ head, $\mathrm{C} \$ 6.36 / \mathrm{head}$, and $\mathrm{C} \$ 4.11 / \mathrm{head}$ for Southcentral, Southeastern and Southwestern Ontario, respectively (Table 6).

For an average 175-head feedlot in Ontario, the revenue loss is expected to be $\mathrm{C} \$ 961$ for each additional day of delay, which is equivalent to $C \$ 28,830$ for 30 days of delay. First cut timing for hay for beef is variable but is often mid-June to early-July.

Table 6. Average change in annual dairy and beef cattle performance per day of delayed harvest across Ontario and in each region

\begin{tabular}{lllll}
\hline & $\begin{array}{l}\text { Province-wide } \\
\text { Ontario }\end{array}$ & Southwest & Southcentral & Southeast \\
\hline Milk production change $(\mathrm{kg} / \mathrm{yr} / \mathrm{cow})$ & -10.9 & -10.27 & -6.44 & -7.15 \\
Value of milk production change $(2017 \mathrm{C} \$ / \mathrm{yr} / \mathrm{cow})$ & $-\mathrm{C} \$ 7.87$ & $-\mathrm{C} \$ 7.41$ & $-\mathrm{C} \$ 4.65$ & $-\mathrm{C} \$ 5.16$ \\
Beef bodyweight gain $(\mathrm{g} / \mathrm{d} / \mathrm{head})$ & -1.56 & -1.16 & -1.97 & -1.79 \\
Value of beef bodyweight gain $(2017 \mathrm{C} \$ / 400 \mathrm{~d} / \mathrm{head})$ & $-\mathrm{C} \$ 5.49$ & $-\mathrm{C} \$ 4.11$ & $-\mathrm{C} \$ 6.96$ & $-\mathrm{C} \$ 6.36$ \\
\hline
\end{tabular}

\subsection{Results: Impact on Cost of Production and Economics}

Another method to analyze the cost of delaying forage harvest is to compare production costs, in this case feed costs, using forage harvested on different dates. The outputs must be for the entire season, so the cost of inputs may be fairly compared. By estimating the cost of the different forages and using the predicted feed intakes, the 
production cost of raising an animal through its phases can be estimated.

For beef cows and steers the following assumptions were used for yield calculations and costs:

- A blend of $75 \%$ timothy and $25 \%$ red clover was being fed

○ This assumption was used to estimate yield. This is reasonable for the sampled forages. All predictions for DM required per animal were calculated from the sampled forages.

- Cuts would be spaced 35 days apart but could be pushed to 30 days if needed.

- Critical fall harvest period for clover determined when another cut was no longer feasible. August $31^{\text {st }}$ was used as the last day to cut for Southcentral, Southeastern and Southwestern Ontario.

- For simplicity, cuts 2 and 3 were considered of equal quality to the first cut. Few comparable estimates are available.

- Total estimated forage yield was calculated as the sum of yield from cuts 1,2 and where possible cut 3 . Total yield was estimated for each date of hypothetical first cut with second and third cuts 35 days after the previous cuts.

- Estimated yield (from Ontario Ministry of Agriculture, Food and Rural Affairs, 2016) for first cut were $1200 \mathrm{~kg} / \mathrm{ac}$ in the last week of May rising to $2200 \mathrm{~kg} / \mathrm{ac}$ in August. Estimated second cut yields were $650 \mathrm{~kg} / \mathrm{ac}$ when the first cut occurred in late May dropping to $375 \mathrm{~kg} / \mathrm{ac}$ when the first cut occurred in the last week of July and zero after that. Estimated third cut yields were $450 \mathrm{~kg} / \mathrm{ac}$ when the first cut occurred in late May, dropping to $281 \mathrm{~kg} / \mathrm{ac}$ when the first cut occurred in the third week of June and zero after that.

- Per acre costs were estimated using the 2017 edition of Ontario Ministry of Agriculture, Food, and Rural Affairs' Publication 60: Field Crop Budget for Alfalfa-Timothy Hay and the 2016 Farmland Value and Rental Value Survey (Deaton, 2017)

- Variable costs such as fuel, labour and custom work were adjusted based on the number of cuts undertaken

- Rent costs were C $\$ 75, C \$ 115$, and $C \$ 140$ /acre for Southcentral, Southeastern and Southwestern Ontario, respectively.

To determine the cost of delayed harvest, the production cost per acre of hay was estimated and average estimated yields were taken from Ontario Ministry of Agriculture, Food and Rural Affairs (2016). Then estimated production costs per acre were used to calculate the feed cost per $\mathrm{kg}$ of DM, using the following formulae.

$$
\text { Feed Cost }=\frac{\text { Cost } / \text { Acre }}{\mathrm{kgDM} / \text { Acre }}
$$

Next, the amount of DM required per animal during their phase of production was calculated assuming they were fed solely on the sampled forage.

$$
\text { DM req.per Animal }=\text { DMI }\left(\frac{\mathrm{kg}}{\mathrm{d}}\right) \times \text { Days on Feed }
$$

Using the cost of the sampled forage $(\mathrm{C} \$ / \mathrm{kg}$ of $\mathrm{DM})$ and the DM requirements, the cost of feeding one steer or cow through their respective production phase was determined.

$$
\text { Cost per Animal }=\frac{\text { Feed } \text { Cost }}{\mathrm{kg} D M} \times \frac{\text { DM req }}{\text { Animal }}
$$

Finally, the following equation was used to determine the cost per acre of delayed harvest:

$$
\begin{aligned}
& \text { Cost } / \text { Animal }_{\text {mid-June }}=\text { Cost } / \text { Animal }_{\text {mid-July }} \\
& \text { Cost } / \text { Animal }_{\text {mid-June }}=D M r e q_{\text {mid-July }} \times \frac{\text { Subsidized Cost } / \text { Acre }_{\text {mid-July }}}{\mathrm{kgDM} / \text { Acre }_{\text {mid-July }}}
\end{aligned}
$$

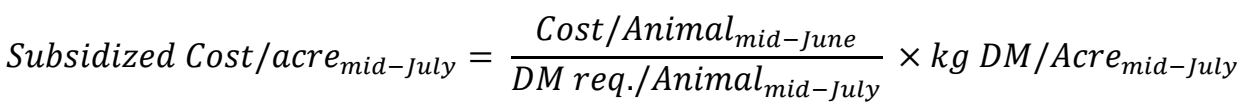

$$
\begin{aligned}
& \text { Loss of Delayed Harvest }=\text { Original Cost per Acre }- \text { Subsidized Cost per Acre }
\end{aligned}
$$

Cost/Animal $_{\text {mid-June, }}$ DM requirement mid-July $_{\text {and }} \mathrm{kg}$ of DM/Acre mid-July $_{\text {were }}$ calculated. Subsidized Cost/Acre mid-July $_{\text {was }}$ the calculated cost of production, of a first cut taken in mid-July that would need to be met to match the cost per animal of a $1^{\text {st }}$ cut taken in mid-June. 


\subsubsection{Backgrounding Steers}

For backgrounding steers, a target rate of an Average Daily Gain (ADG) of $0.6 \mathrm{~kg} / \mathrm{d}$ was selected for the models as it was predicted that forages sampled in both mid-June and mid-July could both meet this target, with the only variable being the intake required to meet the target. This allowed for the cost of delayed harvest to be estimated on a per acre basis as it is assumed that other costs associated with raising a steer (housing, labour, etc.) would remain constant as the predicted time to finishing weight was the same for steers fed the mid-June and the mid-July first cuts.

Table 7 shows the average estimates of production impact per acre. Average dry matter intake (DMI) increases May-August to meet the average daily gain (ADG) target as forage quality decreases. As quality decreases, average days to finish, and average dry matter required all increase. As date of first cut increases, the likelihood of a second or third cut decreases, reducing cost per acre. As dry matter intake increases, average cost per steer increases.

Table 7. Estimate of mean production and economic impact and change over season for forage production, backgrounding steers and wintering beef cows on forage harvested May-August

\begin{tabular}{|c|c|c|c|c|}
\hline & Mean & $\begin{array}{l}\text { Percent change } \\
\text { over season }\end{array}$ & $\begin{array}{l}\text { Correlation with } \\
\text { date of first cut }{ }^{1}\end{array}$ & $\mathrm{R}^{2}$ \\
\hline \multicolumn{5}{|l|}{ Forage Production } \\
\hline Dry Matter Intake (kg/d) & 6.84 & $14.5 \%$ & $0.968 * * *$ & $93.8 \%$ \\
\hline Average Daily Gain (kg/d) & 0.584 & $-11.4 \%$ & $-0.822 * * *$ & $67.5 \%$ \\
\hline Days to Finish & 309.98 & $+13.8 \%$ & $0.815 * * *$ & $66.4 \%$ \\
\hline Dry Matter Required (kg) & 2125.7 & $+28.8 \%$ & $0.914 * * *$ & $83.6 \%$ \\
\hline Cost/ acre & $\mathrm{C} \$ 401.20$ & $-19.6 \%$ & $-0.804 * * *$ & $64.6 \%$ \\
\hline Cost/ kg Dry Matter & $\mathrm{C} \$ 0.1481$ & $-5.7 \%$ & -0.324 & $10.5 \%$ \\
\hline \multicolumn{5}{|l|}{ Backgrounding Beef Steers } \\
\hline Cost/ beef steer & $\mathrm{C} \$ 314.42$ & $23.5 \%$ & $0.656^{*}$ & $43.1 \%$ \\
\hline \multicolumn{5}{|l|}{ Wintering Beef Cows } \\
\hline Cost/ beef cow & $C \$ 200.36$ & $20.2 \%$ & $0.703^{* *}$ & $49.4 \%$ \\
\hline
\end{tabular}

Figure 2 shows the variation in production cost per animal for forage first cut on a certain date over the May to August season. This shows optimal harvest period in June and the cost increases when using late harvest forages to feed backgrounding beef steers and wintering beef cows.

On a per acre basis, the value lost from delaying $1^{\text {st }}$ cut from mid June to mid July, when backgrounding steers was found to be approximately $\mathrm{C} \$ 31$ provincially, or $\mathrm{C} \$ 42, \mathrm{C} \$ 36$, and $\mathrm{C} \$ 32$ per acre (2017) for Southcentral, Southeastern and Southwestern Ontario respectively. 


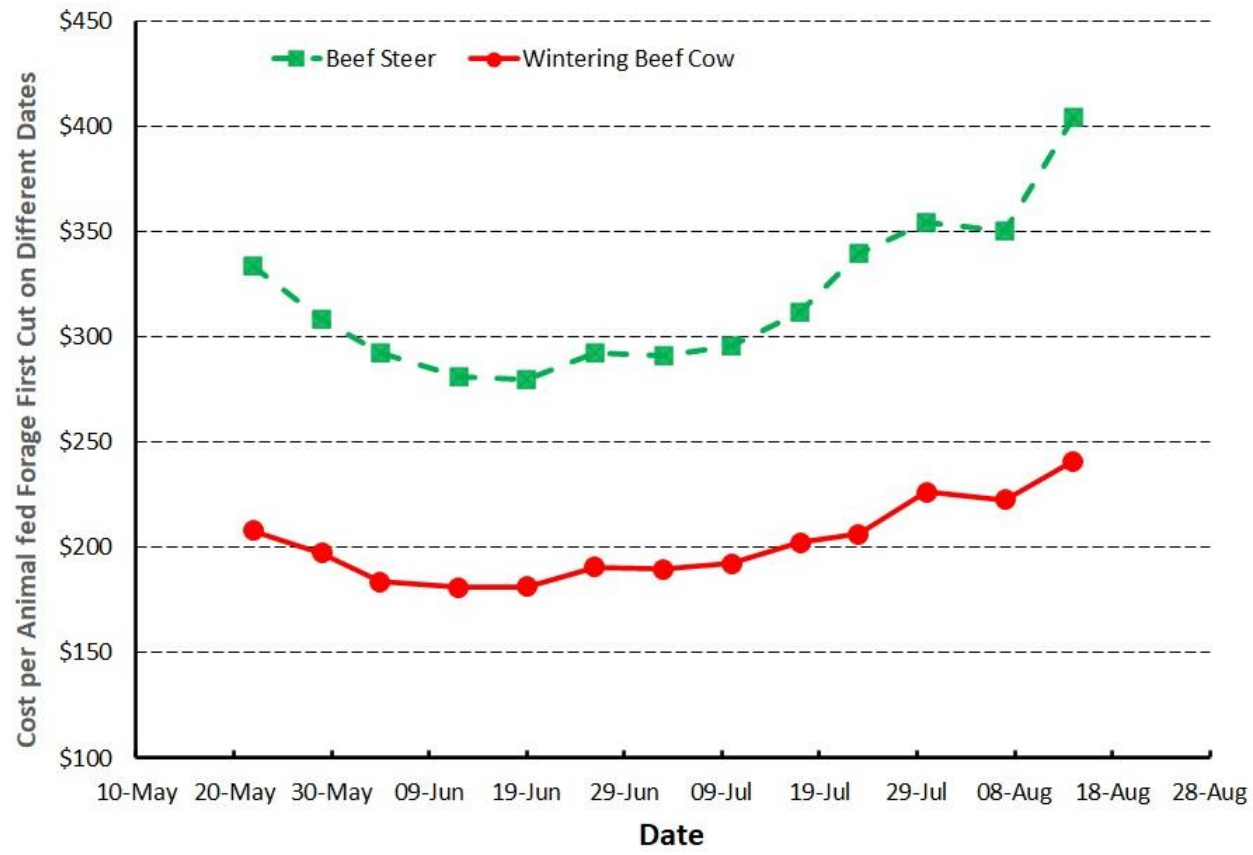

Figure 2. Estimated cost per animal (C\$2017) for wintering beef cows and backgrounding beef steers fed rations including forage first cut on different dates May-August

\subsubsection{Wintering Beef Cows}

For wintering beef cows, the reported feed intakes are the same as those used in the previous section on beef cows (Section 3.2.3). Table 7 and Figure 2 present estimates of costs for wintering beef cows using hay first harvested at different stages in the season. Intake of dry matter would increase over the season as nutritional quality decreases. Average cost per cow increases due to the increased intake required to provide nutrition.

On a per acre basis, the value lost from delaying $1^{\text {st }}$ cut from mid-June to mid-July, when feeding cows over winter, was found to be approximately $\mathrm{C} \$ 45$ provincially, or $\mathrm{C} \$ 66, \mathrm{C} \$ 45$, and $\mathrm{C} \$ 46$ per acre for Southcentral, Southeastern and Southwestern Ontario respectively (Table 8) reflecting regional differences (2017 values).

Table 8. Estimated cost per acre of reduced production value due to use of hay harvested mid-July compared to mid-June (C\$2017)

\begin{tabular}{lllll}
\hline & Provincial & Southwest & Southcentral & Southeast \\
\hline Backgrounding steers & $\mathrm{C} \$ 31 /$ acre & $\mathrm{C} \$ 32 /$ acre & $\mathrm{C} \$ 42 /$ acre & $\mathrm{C} \$ 36 /$ acre \\
Wintering beef cows & $\mathrm{C} \$ 45 /$ acre & $\mathrm{C} \$ 46 /$ acre & $\mathrm{C} \$ 66 /$ acre & $\mathrm{C} \$ 45 /$ acre \\
\hline
\end{tabular}

\section{Discussion}

Hay crops and pasture exist to produce feed for livestock and the livelihoods of farmers. Yet their existence creates what biologists call surrogate or secondary nesting habitat for grassland bird species like the Bobolink and Eastern Meadowlark, suggesting multiple management objectives and potential trade-offs. Delayed hay harvest is often recommended by biologists to benefit the survival of grassland birds, like Bobolink and Eastern Meadowlark (Put et al., 2020; Campomizzi et al., 2019; Pintaric, 2018; Brown and Nocera, 2017; Diemer and Nocera, 2016), and also for European farmland birds (OECD, 2019; Broyer et al., 2016). The nutritional quality of perennial forages (hay) inevitably declines over the growing season (Moore et al., 2020; Karn et al., 2004; Ball et al., 2001; Upfold and Wright, 1994). The production and profitability of farms are necessarily affected by delayed hay cutting.

This study quantified the nutritional quality of forages across the entire season beyond typical harvest dates to assess the impact of delayed hay harvest on beef weight gain and dairy milk production. In a new contribution, using nutritional and economic modeling, yield, cost and price data, this study projected the economic impact of a delayed first cut on dairy and beef production per animal, per day of harvest delay, per acre, and for an average farm operation. This provides scientific evidence to inform incentive program design and educational materials 
for on-farm decision-making. It also contributes to a priority research topic identified in the recovery strategy for these threatened species (Ontario Ministry of Environment, Conservation and Parks, 2020; McCracken et al., 2013).

Timing of Bobolink fledging generally begins in mid-June and often peaks in late June or early July (Pintaric, 2018; Brown and Nocera, 2017; Diemera and Nocera, 2016), although there can be significant annual and geographic variation. There are also geographic differences in the seasonal change of nutritional quality, as revealed in this study and Brown and Nocera (2017). Delay of harvest until July 15 is thought to allow fledging of most nestlings (Put et al., 2020; Kyle and Reid, 2015). Delay until July 1 may allow 80-90\% of young to fledge (Mussell et al., 2013). This study links knowledge of bird fledging and survival with nutritional value and economic impact and allows a detailed empirical basis for trade-offs and optimization between bird conservation and livestock production (also see Brown and Nocera, 2017).

Inter-disciplinary research on grassland bird BMPs would better integrate the assessment of their ecological efficacy with production, economics, and on-farm practicality. European researchers have done more interdisciplinary work including both conservation and agricultural researchers to assess different aspects of projects (e.g., Tallowin and Jefferson, 1999). Inter-disciplinary approaches should be considered for future projects in Canada, such as coupling forage analysis, nutritional modeling, economic analysis, and bird ecology and nesting studies.

The results of this study will support on-farm decision-making by farmers and landowners, providing science-based estimates of the economic and production impacts of delaying the first cut of hay until after July 15 , commonly recommended to benefit grassland birds. For example, a farmer considering the suggested BMPs for delayed haying (Kyle and Reid, 2015), would be better able to assess the impact those practices would have on production and income. Combined with data on bird survival, this makes it easier to assess the economic impact of cutting one or more fields later to benefit bird nesting.

The findings will also ensure the design of stewardship programs can be based on scientific evidence. Considerable research has gone into evidence on bird survival and reproduction. The estimates of reduced production values in this study support the cost sharing values and approaches taken under the Species at Risk Partnerships on Agricultural Land program for delayed haying (Ontario Soil and Crop Improvement Association, 2018 , 2022). So, the research supports both informed farm-level decision making by farmers and evidence-informed decisions in program and policy design.

\section{Acknowledgements}

Thanks to the farmer cooperators who allowed use of their land and forage crops for sampling and to the volunteers and summer students that collected the forage samples. Many people contributed to the study including Joel Bagg, Gabe Ferguson, Laura Van Vliet, Christine O'Reilly, and Christine Schmalz. Thanks to Aaron Smith, Jon McCracken and Ron Reid for their reviews of documents. Funding sources for this study included the Best Management Practices Verification and Development Program of Ontario Ministry of Agriculture, Food and Rural Affairs and the Species at Risk Partnerships on Agricultural Lands (SARPAL) program of Environment and Climate Change Canada, administered in Ontario by the Ontario Soil and Crop Improvement Association.

\section{References}

Ball, D., Collins, M., Lacefield, G., Martin, N., Mertens, D., Olson, K., Putnam, D., Undersander, D., \& Wolf, M. (2001). Understanding forage quality. American Farm Bureau Federation Publication 1-01, Park Ridge, IL, USA. Retrieved from https://pss.uvm.edu/pdpforage/Materials/ForageQuality/Understanding_Forage_Quality_Ball.pdf

Berdahl, J., Karn, J., \& Hendrickson, J. (2004). Nutritive quality of cool-season grass monocultures and binary grass-alfalfa mixtures at late harvest. Agronomy Journal, 96, 951-955. https://doi.org/10.2134/agronj2004.0951

Bonnefield Research. (2016). Canada's forage crop the overlooked cornerstone of Canadian agriculture. Bonnefield, Toronto. Retrieved from https://bonnefield.com/wp-content/uploads/pdf/Canadas_Forage_Crop.pdf

Brown, L., \& Nocera, J. (2017). Conservation of breeding grassland birds requires local management strategies when hay maturation and nutritional quality differ among regions. Agriculture, Ecosystems and Environment, 237, 242-249. https://doi.org/10.1016/j.agee.2016.11.004 
Broyer, J., Sukhanova, O., \& Mischenko, A. (2016). How to sustain meadow passerine populations in Europe through alternative mowing management. Agriculture, Ecosystems and Environment, 215, 133-139. https://doi.org/10.1016/j.agee.2015.09.019

Campomizzi, A., Lebrun-Southcott, Z., Van Vliet, L., \& Morris, G. (2019). Rotational grazing of beef cattle to support Bobolink breeding success. Avian Conservation and Ecology, 14(2), 13. https://doi.org/10.5751/ACE-01420-140213

Chakrabarti, A., Chase, L., Strong, A., \& Swallow, S. (2019). Making markets for private provision of ecosystem services: The Bobolink Project. Ecosystem Services, 37, 100936. https://doi.org/10.1016/j.ecoser.2019.100936

Deaton, B. (2017). 2016 Farmland value and rental value survey. Retrieved from https://www.uoguelph.ca/fare/files/Rental-Survey-Feb_15_report_AODA.pdf

Diemera, K., \& Nocera, J. (2016). Bobolink reproductive response to three hayfield management regimens in southern Ontario. Journal for Nature Conservation, 29, 123-131. https://doi.org/10.1016/j.jnc.2015.12.007

Ethier, D., \& Nudds, T. (2015). Scalar considerations in population trend estimates: Implications for recovery strategy planning for species of conservation concern. Condor, 117, 545-559. https://doi.org/10.1650/CONDOR-15-89.1

Ethier, D., Koper, N., \& Nudds, T. (2017). Spatiotemporal variation in mechanisms driving regional-scale population dynamics of a Threatened grassland bird. Ecology and Evolution, 7(12), 4152-4162. https://doi.org/10.1002/ece3.3004

Fisher, J. (2008). Estimating the value of Ontario's forage industry. Ontario Forage Council, CORD IV, and the University of Guelph.

Foster, A., Biligetu, B., Malhi, S., Gill, K., Mollison, B., \& Leach, D. (2021). Harvest time and fertility effects on yield and quality of forage from alfalfa, hybrid bromegrass and their mixture. Agricultural Sciences, 12, 325-338. https://doi.org/10.4236/as.2021.124021

Fromberger, M., Campomizzi, A., Lebrun-Southcott, Z., Pintaric, A., MacDonald, N., \& Nol, E. (2020). Factors affecting Bobolink nest survival across grassland types. Avian Conservation and Ecology, 15(2), 13. https://doi.org/10.5751/ACE-01666-150213

Hill J., Egan, J., Stauffer, G., \& Diefenbach, D. (2014). Habitat availability is a more plausible explanation than insecticide acute toxicity for U.S. grassland bird species declines. PLoS ONE, 9(5), e98064. https://doi.org/10.1371/journal.pone.0098064

Jensen, K., Robins, J., Rigby, C., \& Waldron, B. (2017). Comparative trends in forage nutritional quality across the growing season in 13 grasses. Can. J. Plant Sci., 97, 72-82. https://doi.org/10.1139/CJPS-2015-0328

Johnson, A. (2020). Species at Risk Partnerships on Agricultural Lands (SARPAL) rapid impact evaluation. Major Paper, Master's in Environmental Studies, Faculty of Environmental and Urban Change, York University, Toronto, Ontario, Canada. Retrieved from https://yorkspace.library.yorku.ca/xmlui/bitstream/handle/10315/38367/MESMP03467_Johnson_A.pdf

Kyle, J., \& Reid, R. (2015). Farming with Grassland Birds: A guide to making your hay and pasture bird friendly. Ontario Soil and Crop Improvement Association.

Macdonald, N., \& Nol, E. (2017). Impacts of rotational grazing and hay management on the reproductive success of Bobolink (Dolichonyx oryzivorus) in Eastern Ontario, Canada. Canadian Wildlife Biology and Management, 6, 53-65.

McCracken, J., \& Crews, B. J. (2013). Bobolink/Meadowlark Round Table. Progress Report \#3. Compiled by Jon McCracken and Bette Jean Crews.

McCracken, J., Reid, R., Renfrew, R., Frei, B., Jalava, J., Cowie, A., \& Couturier, A. (2013). Recovery strategy for the Bobolink (Dolichonyx oryzivorus) and Eastern Meadowlark (Sturnella magna) in Ontario. Ontario Recovery Strategy Series. Prepared for the Ontario Ministry of Natural Resources, Peterborough, Ontario. pp. 88.

Moore, K., Lenssen, A., \& Fales, S. (2020). Factors affecting forage quality. In K. Moore, M. Collins, C. Nelson, \& D. Redfearn (Eds.), Forages, Volume 2: The Science of Grassland Agriculture (pp. 701-717). Wiley-Blackwell. https://doi.org/10.1002/9781119436669.ch39 
Mussell, A., Schmidt, C., Ethier, D., \& Yungblut, D. (2013). Synthesis of knowledge on agricultural practices related to grassland bird habitat. George Morris Centre, Guelph, ON.

National Academies of Sciences, Engineering, and Medicine. (2016). Nutrient requirements of beef cattle: eighth revised edition. Washington, DC: The National Academies Press. https://doi.org/10.17226/19014.

National Research Council. (2001). Nutrient requirements of dairy cattle: seventh revised edition, 2001. Washington, DC: The National Academies Press. https://doi.org/10.17226/9825

Nocera, J., Parsons, G., Milton, G., \& Fredeen, A. (2005). Compatibility of delayed cutting regime with bird breeding and hay nutritional quality. Agriculture, Ecosystems and Environment, 107, 245-253. https://doi.org/10.1016/j.agee.2004.11.001

North American Bird Conservation Initiative Canada. (2019). The state of Canada's birds, 2019. Environment and Climate Change Canada, Ottawa, Canada.

Ontario Ministry of Agriculture, Food and Rural Affairs. (2009). Agronomy guide for field crops. Publication 811.

Ontario Ministry of Agriculture, Food and Rural Affairs. (2016). Feed analysis reports explained. Factsheet.

Ontario Ministry of Agriculture, Food and Rural Affairs. (2017). Field crop budgets. Publication 60. Retrieved from http://www.omafra.gov.on.ca/english/busdev/facts/pub60.pdf

Ontario Ministry of Environment, Conservation and Parks. (2020). Protection and recovery of Ontario's Species at Risk 2020 review of progress summary.

Ontario Ministry of Natural Resources and Forestry. (2015). Bobolink and Eastern Meadowlark government response statement. Retrieved from

https://www.ontario.ca/page/bobolink-and-eastern-meadowlark-government-response-statement

Ontario Ministry of Natural Resources and Forestry. (2016). Bobolink general habitat description. Retrieved from https://www.ontario.ca/page/bobolink-general-habitat-description

Ontario Soil and Crop Improvement Association. (2018). The Grassland Stewardship Program. Species at Risk Partnerships on Agricultural Lands (SARPAL). Retrieved from https://www.ontariosoilcrop.org/oscia-programs/sarpal-xx/gsp/

Ontario Soil and Crop Improvement Association. (2022). Species At Risk Partnerships on Agricultural Lands. Retrieved from https://www.ontariosoilcrop.org/oscia-programs/sarpal/

Organisation for Economic Cooperation and Development (OECD). (2019). Trends and drivers of agri-environmental Performance in OECD Countries. OECD Publishing, Paris. https://doi.org/10.1787/b59b1142-en

Palmonari, A., Fustini, M., Canestrari, G., Grilli, E., \& Formigoni, A. (2014). Influence of maturity on alfalfa hay nutritional fractions and indigestible fiber content. J. Dairy Sci., 97, 7729-7734. https://doi.org/10.3168/jds.2014-8123

Perkins, A., Maggs, H., Watson, A., \& Wilson, J. (2011). Adaptive management and targeting of agrienvironment schemes does benefit biodiversity: a case study of the corn bunting Emberiza calandra. Journal of Applied Ecology, 48, 514-522. https://doi.org/10.1111/j.1365-2664.2011.01958.x

Perlut, N., Strong, A., \& Alexander, T. (2011). A model for integrating wildlife science and agri-environmental policy in the conservation of declining species. Journal of Wildlife Management, 75, 1657-1663. https://doi.org/10.1002/jwmg.199

Pintaric, A. (2018). The impact of agricultural land use on Bobolink occurrence, abundance, and reproductive success in an alvar landscape. M.Sc. Thesis, Trent University, Peterborough, Ontario, Canada.

Put, J., Campomizzi, A., \& Lebrun-Southcott, Z. (2020). Determining when bobolink finish breeding to time agricultural activity in nesting refuges. J. Wildl. Mgt., 84, 468-477. https://doi.org/10.1002/jwmg.21826

Renfrew, R., Peters, K., Herkert, J., VanBeek. K., \& Will, T. (2019). A full life cycle conservation plan for Bobolink (Dolichonyx oryzivorus). U.S. Fish \& Wildlife Service.

Roche, J., Berry, D., Bryant, A., Burke, C., Butler, S., Dillon, P., Donaghy, D., Horan, B., Macdonald, K., \& Macmillan, K. (2017). A 100-Year Review: A century of change in temperate grazing dairy systems. $J$. Dairy Sci., 100, 10189-10233 https://doi.org/10.3168/jds.2017-13182 
Shew, J., \& Nielsen, C. (2021). Differential effects of policy-based management on obligate and facultative grassland birds. Agriculture, Ecosystems \& Environment, 319, 107411. https://doi.org/10.1016/j.agee.2021.107411

Smith, P. G. R. (2015). Long-term temporal trends in agri-environment and agricultural land use in Ontario, Canada: transformation, transition and significance. Journal of Geography and Geology, 7, 32-55. https://doi.org/10.5539/jgg.v7n2p32

Smith, P. G. R. (2018). Working lands, conservation and cooperation: agricultural grasslands and grassland birds in Ontario. In L. Knuffman (Ed.), America's grasslands conference: united for grassland conservation (pp. 44-46). Proceedings of the 4th Biennial Conference on the Conservation of America's Grasslands. Fort Worth, TX. Washington, DC: National Wildlife Federation.

Stanton, R., Morrissey, C., \& Clark, R. (2018). Analysis of trends and agricultural drivers of farmland bird declines in North America: A review. Agriculture, Ecosystems and Environment, 254, 244-254. https://doi.org/10.1016/j.agee.2017.11.028

Swallow, S., Anderson, C., \& Uchida, E. (2018). The Bobolink Project: selling public goods from ecosystem services using provision point mechanisms. Ecological Economics, 143, 236-252. https://doi.org/10.1016/j.ecolecon.2017.06.040

Tallowin, J., \& Jefferson, R. (1999). Hay production from lowland semi-natural grasslands: a review of implications for ruminant livestock systems. Grass and Forage Science, 54, 99-115. https://doi.org/10.1046/j.1365-2494.1999.00171.x

Upfold, R., \& Wright, H. (1994). Forage production. Publication 30, Order \#30, Agdex \#120. Ontario Ministry of Agriculture, Food and Rural Affairs.

Weiss, W., \& Hall, M. (2020). Laboratory methods for evaluating forage quality. In K. Moore, M. Collins, C. Nelson, \& D. Redfearn (Eds.), Forages, Volume 1: An Introduction to Grassland Agriculture (pp. 659-672). Wiley Blackwell. https://doi.org/10.1002/9781119436669.ch36

Wells, M., Cant, J., Smith, P. G. R., Kyle, J., Bagg, J., Wright, T., Roberts, P., O’Reilly, C., Van Vliet, L., \& Ramirez, M. (2018). Hay nutritional quality May to August and impact of delaying first cut on dairy and beef production. Project Report, Ontario Soil and Crop Improvement Association. Retrieved from https://www.ontariosoilcrop.org/wp-content/uploads/2018/10/Forage-nutritional-quality-Report-Oct2018.pdf

Wilsey, C., Grand, J., Wu, J., Michel, N., Grogan-Brown, J., \& Trusty, B. (2019). North American grasslands and birds report. National Audubon Society, New York, New York, USA. Retrieved from https://nas-national-prod.s3.amazonaws.com/audubon_north_american_grasslands_birds_report-final.pdf

Yari, M., Valizadeh, R., Naserian, A., Ghorbani, G., Rezvani Moghaddam, P., Jonker, A., \& Yu, P. (2012). Botanical traits, protein and carbohydrate fractions, ruminal degradability and energy contents of alfalfa hay harvested at three stages of maturity and in the afternoon and morning. Animal Feed Science and Technology, 172, 162-170. https://doi.org/10.1016/j.anifeedsci.2012.01.004

Yungblut, D. (2012). National forage and grassland assessment. Report Prepared by: Yungblut \& Associates Inc. Retrieved from http://www.canadianfga.ca/wp-content/uploads/2011/04/V1-Final-June-2012-Report-National-Forage-andGrassland-Assessment-formatted.pdf

\section{Copyrights}

Copyright for this article is retained by the author(s), with first publication rights granted to the journal.

This is an open-access article distributed under the terms and conditions of the Creative Commons Attribution license (http://creativecommons.org/licenses/by/3.0/). 